\title{
Effect of Somatic Cells Level To Lactic Culture Used in the Mozzarella Cheese Processing
}

Karyne Oliveira Coelho (I,II), Albenones José de Mesquita (II), Cíntia Silva Minafra e Rezende (II), Rodrigo Balduino Soares Neves

(I) UEG - Universidade Estadual de Goiás (Rua da Saudade, no56 - Vila Eduarda - São Luís de Montes Belos - GO - CEP 76.100), (II) UFG - Universidade Federal de Goiás (Av. Esperança, s/n - Setor Itatiaia, Goiânia - GO, 74001-970)

\section{Resumo}

The subclinical mastitis is a mammary gland inflammatory reaction that is characterized by increased levels of somatic cells in the milk. The milk with higher somatic cell counting (SCC) shows alteration in the composition that alters the quality of the milk products. Somatic Cells Count (SCC) is a well know parameter used for milk quality evaluation and SCC increase is related to poor cheese manufacture which impairs the cheese flavor, texture and yield. Furthermore, the leucocytes antimicrobial factors which is up regulated in subclinical mastitis could inhibit the culture lactic development, impairing the fermentation and coagulation process of the product. Thus, the objective of this study was to evaluate the effect of somatic cells level of the milk to lactea culture during type mozzarella cheese production. Milk was selected from cattle with SCC £200 thousand cells/mL; CCS > 200 a $£ 400$ thousand cells $/ \mathrm{mL}$ e CCS >400 thousand cells $/ \mathrm{mL}$ as well as cows that have not been antimicrobial treated on the days prior to the raw material collection. The cheese was produced at Plant of Dairy Training Centre Agência Rural from Goias state. Acid lacteal bacterial count, clot time and consistency of the clot were evaluated during the fermentation process and storage of the product. Completely randomized blocks with three repetitions were used as an experimental design. In the statistical analyses variance analysis was used follow by Turkey test, considering significant p400 thousand cells $/ \mathrm{mL}$, and lower 
culture lactea count as well. It was concluded that the increase of SCC has a negative influence to milk culture used in mozzarella cheese manufacturing. The results showed here demonstrated that in order to get a good quality mozzarella cheese is necessary the utilization of the milk with somatic cell counts bellow 400.000 cells $/ \mathrm{mL}$.

Palavras-Chave: fermentation, mastitis, milk, quality

Agência de Fomento: 